\title{
People with physical disabilities on the labour market - abilities required for work self-fulfilment
}

\section{Lucie Procházková}

\begin{abstract}
Finding success on the labour market by people with disabilities is influenced by several factors: their readiness and motivation, the available opportunities, the attitudes of employers and the society, as well as the preparedness of the labour market and the work environment to incorporate them into the work stream. Social and economic advancements demand that the youth be equipped with skills and competences contributing to their full-fledged integration. Objectives: The aim of the research presented herein was to ascertain the experience of people with physical disabilities with the labour market (work conditions, job search reasons, obstacles, etc.). Methods: The main technique of the qualitative research was a semi-structured interview. Participants were people with congenital and acquired restricted mobility (here as a result of multiple sclerosis) with work experience. Based on the obtained information, we formulated the skills and competences that can be seen as necessary for employment in the $21^{\text {st }}$ century. Results: The barriers experienced by people with disabilities in the work environment arise from their disabilities as well as the attitudes of their employers, their openness and friendliness. The overall attitude of the society towards people with disabilities is also perceived as significant.
\end{abstract}

Keywords: work experience, work self-fulfilment, skills and competences, people with disabilities, attitudes, obstacles 


\section{Introduction and Theoretical basis}

Undoubtedly, work is a prerequisite for full-value integration in social life for every human being. Work allows people to achieve recognition, provides them with the possibility of self-fulfilment and social interaction (cf. Procházková 2009, Bieker 2005). Work divides time into working hours and free time, allows regular and systematic activities that go beyond personal purposes, and links working people with the social reality. Thanks to work, people can take on new social roles.

In terms of gainful occupation, Zwierlein (in Niehaus, Montana 1997, p. 18) understands work as "a planned and vigorous action [...] that primarily serves to ensure existence and the satisfaction of needs". Considering the importance of this earning role, Jahoda (1983) distinguishes two functions: overt and latent. The overt work function ensures livelihood through achieving earnings. Latent (hidden) functions refer to those functions that a person usually does not realize. The economic focus of work would thus be the overt function, while the latent (hidden) importance bestowing a meaningful life impletion. These functions can also be seen in the factors (Langmeier, Krejčírová 2006) that in varying degrees motivate people when looking for a job (to gain material benefits, motivation to help people, possibility of self-fulfilment, opportunity to find friendly contacts).

Paid work represents an opportunity to become more independent. Employment allows people to obtain a new status in the society; those "living mainly on social benefits" (people with disabilities are often seen like this) become persons gainfully employed who also pay taxes and insurance contributions (Procházková 2009). In addition to changes in the perceptions and attitudes of the society, work forces them to plan and manage their time, and has a positive impact on their self-perception and selfconfidence as well as on the meaning of their own lives and motivations.

For people with physical disabilities, work has a specific meaning also because it is "publicly visible evidence of their performance and readiness to performance, individual skills are evident rather than the deficits" (Bieker, 2005, p. 16). Inability to fulfil the job role, be gainfully employed, to take care of themselves or their families, or be useful, is reflected in the quality of life of individuals (consequences in the economic and social status, disturbed identity and self-perception, social isolation that may result in deterioration of the whole personality). 


\section{Unemployment and its reasons}

Unemployment threatens more certain groups of people that also include people with disabilities. The reasons for high unemployment among people with disabilities can be found both on the part of employers and the persons with disabilities themselves. Many employers do not have experience with people with disabilities even in normal life, they are not aware of their capabilities and limitations. They cannot imagine what it means to employ a person with a disability, how to integrate such a person into their companies (cf. Procházková 2009, Hrdá 2007). Many people only think of persons with physical disabilities as people in wheelchairs (cf. Novosad 2011, Wolf 2009). The first things they, therefore, reflect upon are (only) the barrier environment, the inability to perform certain activities and limited overall performance, or they are afraid of higher morbidity.

In its questionnaire survey, the Ministry of Labour and Social Affairs generally dealt with the status of people with disabilities on the labour market. Lack of education and professional qualifications for employment was identified as a significant barrier. Furthermore, almost $21 \%$ of the respondents stated that they suffer from deprivation, anxiety and resignation. Another barrier may arise due to limited working capacity and unwillingness to commute or move (VÚPSV, 2011). In people with restricted mobility, commuting can often represent a major (and everyday) concern or a decisive factor in whether to accept a particular job.

Barriers in employment and their impact on satisfaction in people with multiple sclerosis were addressed by Rumrill (Rumrill et al., 2004). The respondents mainly reported barriers in access to work, working conditions and the social environment (temperature in the workplace, the presence of stairs, parking distance). Other obstacles are caused by problems associated with the illness itself (inability to work full-time, low energy, memory problems). Finally, the respondents stated concerns about their future work self-fulfilment due to disease progression.

In the employer, we can see fear of new and unfamiliar things; they do not know how to communicate with these people, how they should behave towards them, they may feel embarrassed, etc. The problems may also include concerns about the high cost of creating jobs suitable for people with disabilities (Michálek, Matysková, 2011). The pressure of competition resulting from the global market enforces greater rationalization and automation while workers are required to perform better and better or are replaced with machines (Bieker, 2005). In people with disabilities, the fundamental cause of difficulties in finding or keeping work is especially their substandard or inadequate education. Furthermore, they have unrealistic ideas about their future careers, lack awareness of the labour market, feature poor social and communication competences as well as insufficient motivation (Procházková in Bartoňová, Vítková et al. 2010). 


\section{Changes in the $21^{\text {st }}$ century}

Due to developments in the society and in the economy, young people must harbour such abilities (skills) and competences that will enable them to benefit from the emerging forms of socialization. Thanks to them, they will be able to actively contribute to the economic development of the system that is dominated by knowledge. These abilities are referred to as the skills and competences characteristic of the $21^{\text {st }}$ century and have to focus on the needs of emerging models of economy and social development rather than to adapt to the industrial mode of production, as has been the case (Ananiadou, Claro 2009).

Education in the school environment and beyond should contribute to shaping social values and attitudes. However, these cannot be acquired only in the school environment; experience and contact with the challenges of everyday life are necessary as well. Practical skills and experience increase the chances on the labour market and positively affect interpersonal relationships, acceptance of differences and the willingness to adapt.

In the $21^{\text {st }}$ century, people will require a set of other skills and competences than the hitherto to function effectively at work as well as citizens beyond work (Dede 2007). This need must be reflected by schools and the education system in preparing students for life after school. Likewise, it must reflected by universities in the preparation of future teachers. It is important not only what knowledge young people acquire during the education process but whether they are able to use their knowledge and skills in everyday life.

In the OECD study focused on the skills and competences for the $21^{\text {st }}$ century, the competences are divided into three dimensions: information, communication, and ethical and social impact (Ananiadou, Claro 2009). People must be able not only to acquire information but also to work with it, draw connections and perceive it as a basis for new ideas. Information is thus understood as a source and as a product. Communication plays an important role in preparing for life in a community where people represent themselves, their opinions and attitudes, being able to express them and also accept the opinions of others. Communication includes the ability to cooperate (teamwork), flexibility, adaptability, but also the ability to communicate effectively. The dimension of ethical and social impact refers to differences in the society and the social responsibility of everyone where the action of one individual can affect the entire society. 


\section{Experiences of people with physical disabilities with the labour market - results of researches}

Within the research project "Special needs of pupils in the context of the Framework Education Programme for Basic Education" (MSM0021622443, principal investigator prof. Dr. M. Vítková, CSc.), we addressed the topic of work and employment of people with disabilities from many angles. This paper summarizes the results of qualitative researches based on semi-structured interviews focused on the experiences of people with disabilities with the labour market. The surveys were conducted on people with congenital and people with acquired physical disabilities.

The aim of one research was to identify the experiences of people with congenital physical disabilities with the labour market, obstacles that they perceive and their reasons for seeking employment (Procházková in Opatřilová 2013). There were three criteria for selecting informants: congenital physical disability (here cerebral palsy, muscular disease, spina bifida), age 25-40 years and the existing labour market experience. A total of 13 interviews were conducted ( 8 with men, 5 with women).

Informants of the other research were people with acquired limited mobility as a result of multiple sclerosis (MS). The aim was to determine the influence of multiple sclerosis on work and job execution. We mainly focused on the possible restrictions, on the work climate and the working conditions, and generally on the opportunities in the labour market (Ondrová, Procházková in Bartoňová, Vítková 2013). The criteria for their selection coincided with the criteria in the previous investigation. In addition to the existence of MS, the criteria were productive age (25-55 years) and employment history. The research group eventually consisted of 7 informants ( 5 women, 2 men) aged 30-55 years. Four informants had university degrees, while three informants graduated from secondary vocational schools. At the time of the research, three of them were already unemployed; two employed informants belonged to the group of self-employed persons.

\section{Summary of the researches and discussion}

The main factors influencing the work self-fulfilment in people with (physical) disabilities are represented by the general perception of people with disabilities in the intact society, the disability itself, employers' attitudes, the barriers in the environment, and the system settings. These research surveys dealt with work experience in two groups of people with limited mobility, congenital and acquired during life. In the results of both surveys, we can observe concordances that specifically relate to restricted mobility and its implications for performing work. Nevertheless, we also perceive differences that may be associated with the time of disability formation and disability nature. 
First, we focus on the differences. Individuals with congenital disabilities (e. g. cerebral palsy) are confronted with certain limitations already from birth and never experienced the situation of finding a job without this handicap. People with acquired disabilities often get their first job before having major health problems and the change sets in later. After acquiring the disability the people fear of physical labour or failure to cope with the pace of work. They distress over changes in the labour collective and fear of how they would be accepted by a new team. When forced to find a new job, informants also considered whether to mention the existence of their disease or not.

Failure in finding a job of people with congenital disabilities are associated with health conditions but relate to the "unserious" conduct of employers and to the general situation in the labour market as well. Informants are aware of the restrictions that can be caused by a physical disability; however, they point to hasty conclusions and evaluations of the employers resulting from the fact that they often do not get the opportunity to present their own abilities. Employers particularly notice the limitations in movement, the crutches or the wheelchair, and not what the person can offer. If a person has a significant physical disability, eventually also combined with a communication disorder, many people assume that such persons also have intellectual disability. This is often the general perception of the society that people with disabilities meet.

Another difference can be seen in the permanency or alterations to the health condition. MS as well as muscle diseases have a progressive course. In these people, it can be expected that their health will deteriorate, which will be also reflected in their work performance. In the opinion of persons with multiple sclerosis, the most serious factors affecting the ability to work are those associated with the disease (symptoms, progression, fatigue) as well as nonmedical factors (age, education, previous practice and work experience). Disease progression and the inability to fulfil job duties are a common reason for leaving the job.

Adjustments to working conditions and the work environment are regarded as necessary for staying in employment. A Canadian research among women with multiple sclerosis (Dyck, Jongbloed 2000) shows that the adjustment of work conditions can greatly enhance people's ability to continue in their work. This requirement has been also cited by informants in our survey. The most helpful measure would be readjustment of working time. Informants would welcome flexible working hours, the opportunity to rest during the day, part-time work with flexible distribution of working hours during the week; working from home would also be an alternative.

In many areas, the experiences and attitudes of informants concur - e. g. barriers at workplace and on the way to work (depends on the weather and the current health status). Difficulties in performing a job are also similar (they vary depending on which movements can be or cannot be performed and how long the person is able to concentrate on work). Compliance is also apparent in the reasons and motivation (or lack of motivation) to work. The key reasons include the need for self-fulfilment, social contacts 
and meaningful fulfilment of the day. Work gives the people a sense of importance and usefulness, and also helps them to cope with psychic problems. People with congenital disabilities want the work to be useful; people with acquired disabilities want the same to remain useful. According to Bradley (sec. cit. Bradley et al. 2004 in Roessler et al. 2011), employment allows people not to perceive just limitations and disability but rather to see themselves as independent and self-sufficient persons.

Financial reasons are more emphasized in people with congenital disabilities. In the Czech Republic with regards to health condition and reduced working capacity, most people with disabilities at productive age receive disability pension. But it does not always allow them to lead a life according to their expectations. Our informants consistently state that people have a distorted idea of the amount of disability pensions and may, therefore, feel that it is sufficient. Another problem is the overall perception of financial support for people with disabilities as an advantage. The informants emphasize that this is a misconception. In people with acquired disabilities, financial difficulties may appear as a result of the deterioration of health, inability to perform their original job and its potential loss. The earning allows both groups to lead an independent and self-determined life.

Successful integration of persons with (physical) disabilities requires an open and friendly approach on the part of employers, colleagues at the workplace, and the entire society. Adjustments to the work environment (barrier-free), working conditions (flexible working hours etc.) and workloads are major contributors in acquiring or preserving jobs for people with disabilities. The willingness of people with disabilities to work on themselves is important as well.

\section{Conclusion}

With regard to the competences specified in the aforementioned OECD study and divided into three dimensions - information, communication, and ethical and social impact (Ananiadou, Claro 2009, p. 8-10) - it is possible to formulate competences currently necessary for successful work self-fulfilment of people with (not only physical) disabilities. Sufficient information, which must be clear, accessible and relevant, can be considered a crucial factor. People with disabilities need to know where to search for information, how to respond and how to use it for other purposes. In case of employment, it may be information regarding the profession, what is required, where to look for job offers, how to write a CV and a cover letter, how to sell own skills and competences, etc. Employers require the ability to work with new technologies and willingness to learn new things. These skills are increasingly proving to be essential and will be taken for granted in the future. In people with disabilities, new technologies can facilitate access 
to information and also allow or facilitate communication and thus compensate for the limitations caused by disabilities.

Communication is a basic human need. It plays an important role in the development of human personality, in integration into the society as well as in the process of teaching and learning. In people with disabilities, we can encounter impaired communication skills with both verbal and nonverbal components. Competences in communication include not only the active component but also the ability to listen to and accept the opinions of others, the ability to cooperate and adapt to the environment in which the person exists. In the work environment, the mentioned technologies may contribute to active involvement of people in the work process as well as beyond it.

The development of communicative competences is emphasized already during training. One of the outputs of the Framework Education Programme for Basic Education (FEP BE 2007, p. 15) is "the use of the acquired communicative skills to build relationships needed for adequate coexistence and quality cooperation with other people". This aspect thus extends into the social and ethical dimensions that relate to social responsibility and impacts of the action of every person.

Modern information and communication technologies blend through all dimensions, and contribute to informedness, communication as well as social interactions. However, they may be tempted to non-compliance with certain language or social rules and lead to depersonalization. In the work sphere, they allow people to work from home, support flexibility (working hours, work place) and can contribute to prejudicefree behaviour. The prospective employer or client is not influenced by the physical appearance of the given person (job seeker) but focuses on the offered skills and services.

Individual dimensions and competences blend together and complement each other. The learning of these features takes place both in the school environment and outside it. People react to everyday experiences, the development of the society, and to the economic and political development. They are always acquiring knowledge, skills and competences that will enable them to obtain and fulfil the role of full-fledged, active and participatory members of the society.

\section{References}

Ananiadou, K., Claro, M. (2009). $21^{\text {st }}$ Century Skills and Competences for New Millennium Learners in OECD Countries, OECD Education Working Papers, No. 41, OECD Publishing. Available on: http://dx.doi.org/10.1787/218525261154

Bieker, R. (Hrsg.) (2005). Teilhabe am Arbeitsleben. Stuttgart: Kohlhammer Verlag.

Dede, C. (2007). Transforming Education for the $21^{\text {st }}$ century: new pedagogies that help all students attain sophisticated learning outcomes. Available on: http://www.thenetwork.typepad.com/ files/dede_21stc-skills_semi-final.pdf 
Dyck, I. \& Jongbloed, L. (2000). Women with Multiple Sclerosis and Employment Issues: a Focus on Social and Institutional Environment. The Canadian Journal of Occupational Therapy. 67, 337-346. [cit. 12.7.2014]. Retrieved from: http://cjo.sagepub.com/content/67/5/337.refs

Hrdá, J. a kol. (2007). Zaměstnávání lidí se zdravotním postižením. Praha: Júš.

Jahoda, M. (1983). Wieviel Arbeit braucht der Mensch? Arbeit und Arbeitslosigkeit im 20. Jahrhundert. Weinheim/Basel: Beltz.

Langmeier, J. \& Krejčířová, D. (2006). Vývojová psychologie. 2. aktual. vydání. Praha: Grada.

Michálek, M. \& Matysková, K. (2011). Několik poznámek na téma "nevidomí a práce“ [online], Nevidomí mezi námi [cit. 18.2.2014]. Dostupné na: http://www.nevidomimezinami.cz/main/nmn/ Texty/Zamestnani/par_poznamek_na_tema.html

Novosad, L. (2011). Tělesné postižení jako fenomén i životní realita. Praha: Portál.

Ondrová, P. \& Procházková, L. (2013). Vliv roztroušené sklerózy na pracovní uplatnění. In Bartoňová, M. \& Vítková, M. et al. Intervence v inkluzivní edukaci dětí, žáků a studentů se zdravotním postižením a jejich pracovní uplatnění. Brno: Masarykova univerzita, 288-301.

PROCHÁZKOVÁ, L. (2009). Podpora osob se zdravotním postižením při integraci na trh práce. Brno: MSD, spol. s. r.o.

Procházková, L. (2013). Pracovní uplatnění osob se zdravotním postižením z pohledu osob s tělesným postižením a zaměstnavatelů. In OPATŘILOVÁ, D. et al. Žáci se zdravotním postižením a zdravotním znevýhodněním v základních školách. Brno: Masarykova univerzita, 99-109.

Procházková, L. (2010). Postoje zaměstnavatelů k zaměstnávání osob se zdravotním postižením. In Bartoňová, M. \& Vítková, M. et al. Vzdělávání žákư se speciálními vzdělávacími potřebami IV. Education of pupils with special educational needs IV. Brno: Paido, 353-359.

Roessler, R., Hennesseay, M., Neath, J., Rumrill, P. \& Nissen, S. (2011). The Employment Discrimination Experiences of Adults with Multiple Sclerosis. The Journal of Rehabilitation. Vol. 77, No. 1. [cit. 5. 3. 2013]. Retrieved from: http://www.questia.com/library/journal/1G1-248093668/theemployment-discrimination-experiences-of-adults

Rumrill, P., Roessler, R., Vierstra, C., Hennesseay, M. \& Staples, L. (2004). Workplace barriers and job satisfaction among employed people with multiple sclerosis: An empirical rationale for early intervention. Journal of Vocational Rehabilitation. 20(3), 177-183.

VÚPSV (2011). Postavení a strategie OZP na trhu práce. [online] portal.mpsv.cz [cit. 13. 3. 2013]. Available on: http://portal.mpsv.cz/sz/obcane/zamestnavani_ozp/helpforthem/hlavni_vystupy_ projektu_a_jejich_prinosy/dotaznikove_setreni_ozp_na_trhu_prace.pdf.

Wolf, S. (2009). Berufliche Integration (körper)behinderter Menschen. Staatliche Förderung privatwirtschaftlicher Arbeitsnachfrage. Oberhausen: ATHENA.

Zwierlein, E. (1997). Leben ohne Arbeit - Eine Alternative?! In Niehaus, M. \& Montada, L. (Hrsg.) Behinderte auf dem Arbeitsmarkt. Wege aus dem Abseits. Frankfurt am Main/New York: Campus, 18-27.

\section{Contact:}

PhDr. Lucie Procházková, Ph.D.

Institute for Research in Inclusive Education

Faculty of Education

Masarykovy University

Poříćí 31a

60300 Brno

Czech Republic

E-mail: prochazkova.lucie@ped.muni.cz 